\title{
The Effect of Papain Enzymes and Probiotic Addition on Feed Towards The Catfish Growth Performance, Feed Utilization Efficiency and Survival Rate in Biofloc Techniques
}

\author{
Kumala Hidayatiningtyas*, Siti Harnina Bintari, Retno Sri Iswari \\ Science Education. Concentration in Biology, Postgraduate Program, Semarang State University, \\ UNNES Postgraduate Campus Jl. Kelud Utara III Semarang 50237. \\ Email*: kumala2711@gmail.com
}

\begin{abstract}
The success of catfish farming (Clarias sp.) is influenced by feed and water quality. The low feed utilization results in high feed production costs. Alternative use of feed using the enzyme papain and probiotics, the papain enzyme is able to hydrolyze proteins into peptides to increase the utilization of protein in feed by the body. In addition, increased digestibility is done by the addition of probiotic bacteria such as Lactobacillus sp., Saccharomyses sp., Azotobacter sp., Streptomyces sp., Aspergillus sp., Trichoderma sp. into food that can increase feed digestibility and nutrient absorption. Water quality is one of the factors that caused a low survival rate of fish. Biofloc technology utilizes microbial activity that can convert organic waste intensively to form a flock that used by fish as a food source. This study aims to examine the effect of papain and probiotics enzyme addition in feed towards the growth, efficiency of feed utilization and survival rate of catfish using biofloc techniques. The research used a Completely Randomized Design (CRD) by five treatments using biofloc maintenance media and five treatments using non-biofloc, each repeated three times. This research used catfish with a density of 1 head $/ \mathrm{L}$ kept for 4 weeks as a test animal, treatment P0 (test feed $0.0 \mathrm{gr} / \mathrm{kg}$ papain enzyme and $0 \mathrm{~mL}$ probiotics), P1 (test feed $0.25 \mathrm{gr} /$ $\mathrm{kg}$ papain enzyme and $1 \mathrm{~mL}$ probiotic), P2 (Test feed $0.25 \mathrm{gr} / \mathrm{kg}$ papain enzyme and $2 \mathrm{~mL}$ probiotics), P3 (Test feed $0.5 \mathrm{gr} / \mathrm{kg}$ papain enzyme and $1 \mathrm{~mL}$ probiotic), $\mathrm{P} 4$ (Test feed $0.5 \mathrm{gr} / \mathrm{kg}$ of papain enzyme and $2 \mathrm{~mL}$ probiotics). The results showed that the addition of the papain and probiotics enzyme in feed with the best dosage was $\mathrm{P} 2$ with biofloc maintenance media that gave a real effect $(\mathrm{P}<0.05)$ on the efficiency of feed utilization and survival, but had no significant effect (P>0.05) on growth of catfish (Clarias sp.). Water quality in the maintenance media is in a decent range for the maintenance of test fish.
\end{abstract}

Keywords: Catfish (Clarias sp.), Papain Enzyme, Probiotics, Biofloc.

\section{INTRODUCTION}

The freshwater fish farming sector in Indonesia has potential to be developed through extensification and intensification. Intensive maintenance requires the right feed quality, on time and on the right amount. Feed as the biggest component in financing, will determine the success of cultivation. Catfish farmers (Clarias sp.) should be more creative and innovative so that the cultivation takes place and develops in an satisfying result. The feed given should be utilized properly by the body, so that fish can grow optimally. One aspect of stunted growth is the use of feed which is still low, this is related to the digestibility of protein which is not optimal. One way to improve the digestibility of feed is by adding the papain and probiotics enzyme. Therefore, this research more discus about the improvement of feed quality by the help of enzymes and microorganisms.

Enzymes are proteins with catalytic activity to reduce the activation energy of a reaction so that the conversion of substrates into products can take place more quickly. One enzyme that has an important role in life is protease, which is a proteolytic enzyme that works to break down proteins into amino acids (Sulasi et al., 2018). One of the exogenous protease enzymes that can be added to feed is papain. Papain is a protease enzyme that is able to hydrolyze proteins into simpler elements, namely peptides to amino acids, which can increase the utilization of feed protein by the body (Watanabe, 1988). In addition to the addition of the enzyme papain, materials that can be used to increase the digestibility of feed with the ability to break down protein feed into simpler compounds are probiotics with a variety of bacteria. Types of bacteria such as Lactobacillus sp., Saccharomyses sp., Azotobacter sp., Streptomyces sp., Aspergillus sp., Trichoderma sp. in probiotics to be added to the feed with the aim of increasing the digestibility of the feed.

Another factor affecting the success of aquaculture is water quality. Water quality will deteriorate during fish rearing due to accumulation of metabolic waste, decomposition of undigested food and damage to biotic material (Fatchurochman et al., 2017). Probioitics can be used to decompose organic or toxic materials in water so that the water quality will be better. Residual feed can reduce the quality of aquaculture media due to increased ammonia content. Fish need protein that is high enough in their feed, but can only retain about $20-25 \%$ protein and the rest will accumulate in water (Stickney, 2005). Biofloc technique is an alternative solution to the problem of cultivation waste which is beneficial because in addition to reducing inorganic nitrogen waste, it can 
also provide protein-supplemented feed for cultivation so as to increase growth and feed conversion ratio. Avnimelech (2009) states that the protein in feces and inedible feed will be broken down by bacteria into the same product.

This study aims to determine the effect of the addition of the enzyme papain and probiotics in feed as well as differences in maintenance media on growth (RGR), efficiency of feed utilization (EPP) and survival rate of catfish. The results of this study are expected to provide information to farmers about the important role of the use of the enzyme papain and probiotics in growth and maintenance media in supporting optimal feed efficiency. So that it can provide recommendations for the best combination of the addition of the enzyme papain and probiotics in biofloc maintenance media to be applied in aquaculture activities.

\section{MATERIALS AND METHODS}

\section{Procedures}

This study used catfish (Clarias sp.) seeds originating from Kudus, Central Java as a test fish. This research was conducted in October-November 2019. The fish used were measuring $5-7 \mathrm{~cm}$ with a density of $1 \mathrm{fish} / 1$ liter of water. The feed used in this study is pellet-shaped commercial feed with a size of $\pm 1-2 \mathrm{~mm}$. Test feed was added to the enzyme papain and probiotics containing Lactobacillus sp. 2.5 x $107 \mathrm{cfu} / \mathrm{ml}$, Saccharomyses sp. $8.2 \times 107 \mathrm{cfu} / \mathrm{ml}$, Azotobacter sp. 1.31 x $106 \mathrm{cfu} / \mathrm{ml}$, Streptomyces sp. 2.42 × $106 \mathrm{cfu} / \mathrm{ml}$, Aspergillus sp. 1.90 x $105 \mathrm{cfu} / \mathrm{ml}$, Trichoderma sp. 2.8 x $105 \mathrm{cfu} / \mathrm{ml}$. Feeding is carried out twice a day, at 06.00 and 17.00 WIB. The maintenance container used in this study is a bucket of 30 pieces with a diameter of $30 \mathrm{~cm}$, height $36 \mathrm{~cm}$ and a volume of water as much as $10 \mathrm{~L}$, which is equipped with simple water circulation to reduce the intensity of water change.

The research used an experimental method using a completely randomized design (CRD) factorial pattern of $2 \times 2$, by 10 research treatments with different dosages of the addition of papainenzymes and probiotic, repetition was performed 3 times. The first factor is the administration of the enzyme papain $0.25 \mathrm{~g} / \mathrm{kg}$ of feed (P1) and $0.5 \mathrm{~g} / \mathrm{kg}$ of feed (P2). While the second factor is the provision of probiotics $1 \mathrm{ml} / \mathrm{kg}$ of feed (P1) and 2 $\mathrm{ml} / \mathrm{kg}$ of feed (P2). Then the maintenance media are distinguished, using biofloc and non-biofloc techniques. The treatments performed are as follows:

Table 1. Test feed formulations

\begin{tabular}{|c|c|c|c|c|c|c|c|c|c|c|}
\hline \multirow{3}{*}{ Feeds composition } & \multicolumn{5}{|c|}{ Biofloc Method } & \multicolumn{5}{|c|}{ Nonbiofloc Method } \\
\hline & \multicolumn{5}{|c|}{ Test Feed } & \multicolumn{5}{|c|}{ Test Feed } \\
\hline & P0 & P1 & $\mathbf{P 2}$ & P3 & P4 & $\mathbf{P 0}$ & P1 & $\mathbf{P 2}$ & P3 & $\mathbf{P 4}$ \\
\hline Papain Enzyme & 0 & $0,25 \mathrm{~g}$ & $0,25 \mathrm{~g}$ & $0,5 \mathrm{~g}$ & $0,5 \mathrm{~g}$ & 0 & $0,25 \mathrm{~g}$ & $0,25 \mathrm{~g}$ & $0,5 \mathrm{~g}$ & $0,5 \mathrm{~g}$ \\
\hline Probiotic & 0 & $1 \mathrm{ml}$ & $2 \mathrm{ml}$ & $1 \mathrm{ml}$ & $2 \mathrm{ml}$ & 0 & $1 \mathrm{ml}$ & $2 \mathrm{ml}$ & $1 \mathrm{ml}$ & $2 \mathrm{ml}$ \\
\hline
\end{tabular}

The selected test fish have been selected based on size, completeness of the body's organs and physical health. Test fish was put in a maintenance container for 5 days to be able to adapt to the environment and new feed.

The data observed in this study including the growth, feed utilization efficiency and survival rate.

- Relative growth rate ( $R G R)$

The relative growth rate can be calculated using the Takeuchi (1988) formula, as follows:

Information:

$$
R G R=\frac{(W t-W o)}{(W o x t)} \times 100 \%
$$

RGR : Relative growth rate (\%/day)

$\mathrm{W}_{\mathrm{t}} \quad$ : Test fish biomass at the end of the study $(\mathrm{g})$

$\mathrm{W}_{\mathrm{o}}$ : Test fish biomass at the beginning of the study (g)

t : Research time (days)

\section{- Feed utilization efficiency (EPP)}

The efficiency value of feed utilization can be determined by the Tacon formula (1987), as follows:

$$
E P P=\frac{(W t-W o)}{F} \times 100 \%
$$

Information:

EPP : Feed utilization efficiency (\%)

$\mathrm{W}_{\mathrm{t}} \quad$ : Test fish biomass at the end of the study(g)

$\mathrm{W}_{\mathrm{o}} \quad$ : Test fish biomass at the beginning of the study $(\mathrm{g})$

F : Amount of feed consumed during the study (g)

- Survival Rate (SR)

According to Effendi (1997), Survival Rate (SR) is the percentage of fish survival that can be calculated using the following formula:

$$
S R=\frac{N_{t}}{N_{o}} x 100 \%
$$


Information:

SR : Fish survival rate $(\%)$

$\mathrm{N}_{\mathrm{t}} \quad$ : Number of Fish at the end of the study (tail)

$\mathrm{N}_{\mathrm{o}} \quad$ : Number of Fish at the beginning of the study (tail)

\section{Data analysis}

Data were analyzed using the factorial variance model (ANOVA). Before ANOVA is performed, the data are normally tested for normality, homogeneity, and additivity tests to find out that the data are normal, homogeneous and additive. Water quality data are analyzed descriptively to support growth.

\section{RESULTS AND DISCUSSION}

\section{Results}

The results of the study by the addition of the papain enzymeand probiotics in feed on growth, feed utilization efficiency and survival of catfish (Clarias sp.) are presented in Table 2

Table 2. Average value of growth rate (RGR), feed utilization efficiency (EPP) and survival (SR) during the study.

\begin{tabular}{|c|c|c|c|c|c|c|}
\hline \multirow{3}{*}{ Treatments } & \multicolumn{6}{|c|}{ Observed variable } \\
\hline & \multicolumn{3}{|c|}{ Biofloc } & \multicolumn{3}{|c|}{ Non-biofloc } \\
\hline & RGR (\%/day) & $\operatorname{EPP}(\%)$ & $\operatorname{SR}(\%)$ & RGR (\%/day) & $\operatorname{EPP}(\%)$ & $\operatorname{SR}(\%)$ \\
\hline $\mathrm{P} 0$ & $1,98 \pm 0,25$ & $58,40 \pm 2,31$ & $90,00 \pm 2,89$ & $1,77 \pm 0,18$ & $52,78 \pm 4,77$ & $90,00 \pm 2,89$ \\
\hline $\mathrm{P} 1$ & $2,13 \pm 0,31$ & $65,21 \pm 2,84$ & $86,67 \pm 5,77$ & $1,97 \pm 0,27$ & $60,67 \pm 3,11$ & $96.67 \pm 2,89$ \\
\hline $\mathrm{P} 2$ & $2,98 \pm 0,24$ & $70,34 \pm 3,01$ & $90,00 \pm 5,77$ & $2,21 \pm 0,23$ & $66,10 \pm 3,81$ & $90,00 \pm 2,89$ \\
\hline P3 & $2,45 \pm 0,26$ & $68,76 \pm 3,81$ & $90,00 \pm 2,89$ & $2,56 \pm 0,34$ & $69,52 \pm 2,53$ & $83,33 \pm 5,77$ \\
\hline $\mathrm{P} 4$ & $2,13 \pm 0,36$ & $60,30 \pm 4,11$ & $90,00 \pm 7,64$ & $2,43 \pm 0,24$ & $63,71 \pm 2,83$ & $86,67 \pm 5,77$ \\
\hline
\end{tabular}

The results of water quality measurements in catfish (Clarias sp.) rearing media during the study are presented in Table 3.

Table 3. Results of water quality parameters in catfish (Clarias sp.) rearing media during the study.

\begin{tabular}{lll}
\hline $\begin{array}{l}\text { Water quality } \\
\text { paremeters }\end{array}$ & $\begin{array}{l}\text { The range of water } \\
\text { quality parameter } \\
\text { values }\end{array}$ & Appropriateness \\
\hline Temperature $\left({ }^{\circ} \mathrm{C}\right)$ & $28-32$ & $25-32$ \\
$\mathrm{pH}$ & $6-8$ & $6,6-8.5$ \\
\hline Information: ${ }^{\mathrm{a} B o y d}(1982),{ }^{\mathrm{b}}$ Zonneveld $(1991),{ }^{\mathrm{c}}$ Robinette $(1976)$
\end{tabular}

\section{Discussion}

\section{- Growth}

The results analysis showed that the addition of the papain and probiotics enzyme into catfish feeds (Clarias sp.) had no significant effect $(\mathrm{P}>0.05)$. Growth in this study is the relative growth rate calculated based on biomass at the end of the study minus the biomass at the beginning of the study then divided by the initial biomass multiplied by the length of the maintenance of the test animals. The RGR value of catfish (Clarias sp.) maintained in successive biofloc media is P0 of $1.98 \pm$ $0.25 \% /$ day, $\mathrm{P} 1$ of $2.13 \pm 0.31 \%$ /day, $\mathrm{P} 2$ of $2.98 \pm 0$, $24 \%$ /day, P3 is $2.45 \pm 0.26 \%$ /day and P4 is $2.13 \pm$ $0.36 \%$ /day. While the RGR value of catfish kept in successive non-biofloc media is $\mathrm{P} 0$ of $1.77 \pm 0.18 \%$ /day. P1 of $1.97 \pm 0.27 \%$ /day, P2 of $2.21 \pm 0.23 \%$ /day, P3 of $2.56 \pm 0.34 \% /$ day and P4 of $2.43 \pm 0.24 \%$ /day. The same RGR value in each treatment showed that growth in catfish (Clarias sp.) was relatively slow.
According to Nirmala and Rasmawan (2010), one of the obstacles that is often faced in fish farming activities is relatively slow growth, so that in achieving the desired size requires a longer time.

Based on this study the growth of catfish (Clarias sp.) in the addition of the enzyme papain with a concentration of $0.25 \mathrm{~g} / \mathrm{kg}$ and at $0.5 \mathrm{~g} / \mathrm{kg}$ showed the same value in the addition of a concentration of probiotics. This is suspected that the increasement of the dose of the papain enzymeand probiotics giving the same effect on each treatment so that it will produce the same relative growth value. Fish growth occurs because of an energy supply contained in the food consumed, meaning that the test feed has excess energy that can be utilized for growth (Sulasi et al., 2018). before growth occurs, the energy needs for maintenance must be met. Feed given to fish should have a complete nutritional content, both protein, fat and carbohydrates and other micronutrients. If the feed lacks non-protein energy (carbohydrates and fats), then the fish will use a portion of protein to meet its energy needs first before protein is used for growth. So that the protein feed is not sufficient, the fish will not grow properly.

\section{- Efficiency offeed utilization}

The analysis results of the efficiency of catfish (Clarias sp.) feed utilization showed that the addition of the papain enzymeand probiotics in the feed had a significant effect $(\mathrm{P}<0.05)$ on the EPP value of catfish. The best value of feed efficiency in this study was the P2 treatment (test feed with the addition of $0.25 \mathrm{gr} / \mathrm{kg}$ of papain enzyme and $2 \mathrm{~mL}$ probiotics) of $70.34 \pm 3.01 \%$ 
on biofloc maintenance media. Papain can increase the digestibility and absorption of protein consumed by fish, so that the utilization of feed can be utilized by the body. In addition, the addition of probiotics can also increase the utilization of feed because it contains microorganisms that are able to produce amylase, lipase, and protease enzymes so that the nutrients in the feed can be maximally utilized in fish digestion. Ghouse (2015), probiotics are living microorganisms that are given in certain amounts into feed or supplements that have beneficial effects on microbial balance in fish intestines and can improve health. Besides the addition of the papain enzyme can increase feed utilization because papain enzyme is able to break down protein into simpler elements so as to increase feed digestibility. The value of the efficient use of feed to indicate whether the feed given to fish can be used efficiently or not. The higher the efficiency of feed utilization, the higher the efficiency of feed used by fish. This is allegedly due to utilizing biofloc media that can improve feed digestibility so that the utilization of catfish (Clarias $s p$.) feeds is more optimal.

Based on research conducted on different maintenance media, showed results of EPP values were not much different. The highest EPP value is P2 at 70.34 $\pm 3.01 \%$ in biofloc media, then P3 in non-biofloc media at $69.52 \pm 2.53 \%$ and $68.76 \pm 3.81 \%$ in biofloc media, then media non-biofloc with a value of $66.10 \pm 3.81 \%$ in $\mathrm{P} 2$ and $65.21 \pm 2.84 \%$ in P1. Then P4 of non-biofloc media was $63.71 \pm 2.83 \%$, P1 of non-biofloc media was $60.67 \pm 3.11 \%$ and $\mathrm{P} 4$ on biofloc media was $60.30 \pm$ $4.11 \%$. Then the lowest EPP values were P0 $58.40 \pm$ $2.31 \%$ and $52.78 \pm 4.77 \%$ both in biofloc and nonbiofloc media. This is presumably because the concentration of the addition of the papain enzyme by $0.25 \mathrm{~g} / \mathrm{kg}$ and probiotics $2 \mathrm{ml} / \mathrm{kg}$ is an addition that can increase feed digestibility so that the utilization of feed in catfish (Clarias sp.) Is more maximal. This value is lower than the research of Yulianingrum et al., (2017) which is $107.66 \pm 1.36 \%$ with the concentration of the addition of probiotics $2 \mathrm{ml} / \mathrm{kg}$ of feed on seasoned catfish (Clarias gariepinus) on biofloc maintenance media. Higher EPP values also occurred in the study of Pranandhira et al., (2018) of $75.94 \pm 4.21$ in the C / N 18 biofloc maintenance media and feeding containing the papain enzyme. The EPP value in this study was higher than Mareta et al., (2017) with the concentration of the papain enzyme $0.25 \mathrm{~g} / \mathrm{kg}$ of feed and $15 \mathrm{ml} / \mathrm{kg}$ of probiotic feed in gouramy fish that was $49.48 \pm 3.81 \%$. Feed digestibility can be used as an indicator of the assessment of the level of feed efficiency given to fish, so the greater the digestibility of feed will increase the utilization of nutrients in the feed.

\section{- Survival Rate}

Analysis results showed that the addition of papain and probiotics enzyme in fish feed with different maintenance media significantly affected $(\mathrm{P}>0.05)$ on the survival of catfish (Clarias sp.). The results showed the highest survival rate on $\mathrm{P} 1$ treatment in non-biofloc media was $96.67 \pm 2.89$, while the lowest survival value was $\mathrm{P} 3$ in non-biofloc media at $83.33 \pm 5.77$. The high survival value is suspected because catfish are able to use the feed well, so that the energy needs for activity, growth and survival can be used properly.

Fish survival is not directly affected by feed. Fish that died were suspected because of stress during the research maintenance. This is suspected due to the quality of water, especially fluctuating temperatures. In this study, although the highest survival rate was in nonbiofloc media (P1), the lowest value was also in nonbiofloc P3, but if averaged on biofloc media, it had a better survival value. This is suspected because the probiotic factor plays a role in the maintenance media. Good water quality will produce a good life too. Provision of probiotics in maintenance media (biofloc) greatly influences the survival of fish. Probiotics provide resistance to the fish and also maintain water quality. So the fish can survive until the end of the study. According to Fitria (2012), the survival rate is strongly influenced by temperature and oxygen content. Temperature is one of the factors that influence growth. Temperature can affect fish activities, such as breathing and reproduction. Water temperature is closely related to dissolved oxygen concentration and the rate of fish oxygen consumption. Age and ability of fish to adapt to the environment are also important factors in the survival of catfish (Clarias sp.).

\section{- Water quality}

Water quality measured during the study was temperature and $\mathrm{pH}$. Based on the results of water quality measurements, it is found that the quality of water quality is still within the feasible range for conducting catfish culture activities (Clarias sp.) and always maintaining within the feasibility range. The results of temperature measurements during research in maintenance media ranged from $28-32^{\circ} \mathrm{C}$. while the $\mathrm{pH}$ ranges from 6-8. Suboptimal acidity $(\mathrm{pH})$ can cause fish stress, susceptible to disease, productivity, and low growth. Minggawati and Saptono (2012) explained that the water used for raising fish must meet the optimal needs of the fish, namely: water temperature ranges from 25-33을 ${ }^{\circ}$, water $\mathrm{pH}$ 6.5-9.0 optimal 7-8.5; Dissolved oxygen (DO) between 3-7 mg / $\mathrm{L}$ is optimal $5-6 \mathrm{mg} / \mathrm{L}$; Ammonia (NH3) and sulfuric acid (H2S) levels of not more than $1 \mathrm{mg} / \mathrm{L}$; Carbon dioxide $(\mathrm{CO} 2)$ is not more than $10 \mathrm{mg} / \mathrm{L}$.

\section{CONCLUSION}

Based on the results, papain enzymeand probiotics addition in feed gave a significant effect $(\mathrm{P}<0.05)$ on the value of the efficiency of feed utilization (EPP) and survival rate (SR) in catfish (Clarias $s p$.) with an 
increase in EPP on the addition of $0,25 \mathrm{gr} / \mathrm{kg}$ of papain enzyme and $2 \mathrm{~mL}$ probiotics in biofloc maintenance media, but the addition of the papain enzymesand probiotic had no significant effect $(\mathrm{P}>0.05)$ on growth calculated in the relative growth rate (RGR); and water quality in fish maintenance media is in the appropriate range for catfish (Claria sp.) farming.

\section{ACKNOWLEDGEMENTS}

The writers would like to say thanks to all those who gave support and advice as well as assisting to carry out of the research, so the writer can finish this research.

\section{REFERENCES}

Avnimelech Y. \& Kochba M. 2009. Evaluation of nitrogen uptake andexcretion by tilapia in bio floc tanks, using $15 \mathrm{~N}$ tracing. Aquaculture 287:163-168.

Boyd, C.E. 1990. Water Quality in Pond for Aquaculture. Alabama Agricultural Experiment Station Auburn University. Birmingham Publishing Co. Alabanma. 482 hlm.

Effendie, M.I. 1997. Biologi Perikanan. Yayasan Pustaka Nusantara, Yogyakarta, $163 \mathrm{Hlm}$.

Fatchurochman, V., Rachmawati, D., Hutabarat, J. 2017. Pengaruh Kombinasi Pemberian Enzim pada Pakan Buatan dan Probiotik pada Media Pemeliharaan terhadap Efisiensi Pemanfaatan Pakan, Pertumbuhan dan Kelulushidupan Ikan Bawal Air Tawar (Colossoma macropomum). Journal of Aquaculture Management and Technology. 6(3):30-39.

Fitria, A.S. 2012. Analisis Kelulushidupan dan Pertumbuhan Benih Ikan Nila Larasati (Oreochromis niloticus) F5 D30-D70 pada Berbagai Salinitas. [Skripsi]. Fakultas Perikanan dan Ilmu Kelautan, Universitas Diponegoro. Journal of Aquaculture Management and Technology 1 (1): 18-34 hlm.

Ghouse, M.S. 2015. Use of Probiotics as Biological Control Agents in Aquaculture for Sustainable Development. International Journal of Food, Agriculture and Veterinary Science. 5(1): 112-119.
Minggawati, I dan Saptono.2012. Parameter kualitas air untuk budidaya ikan patin (pangasius pangasius) di karamba Sungai Kahayan, Kota Palangka Raya. Jurnal Ilmu Hewani Tropika, 1(1): $27-30$

Nirmala K. Dan Rasmawan. 2010. Kinerja Pertumbuhan Ikan Gurame (Osphronemus gouramy) yang dipelihara pada Media Bersalinitas dengan Paparan Medan Listrik. Jurnal Akuakultur Indonesia., 9(1): 46-55.

Pranandhira, G., Subandiyono, Sudaryono, A. 2018. Pengaruh media pemeliharaan yang berbeda dengan pemberian pakan mengandung enzim papain terhadap efisiensi pemanfaatan pakan dan pertumbuhan ikan patin (Pangasius hypopthalmus). Jurnal Sains Teknologi Akuakultur. 2(1):43-50

Robinette, H.R. 1976. Effect of Sublethal Level of Ammonia on The Growth of Channel Catfish (Ictalarus punctatus R.) Frog. Fish Culture, 38 (1): 26-29 hlm.

Stickney RR. 1979. Principal of Warmwater Aquacultur. John Wiley and Sons. Inc. A wiley-Interscience Publication. New York. USA. 375 p.

Sulasi, Hastuti, S., Subandiyono. 2018. Pengaruh Enzim Papain dan Probiotik pada Pakan Buatan terhadap Pemanfaatan Protein Pakan dan Pertumbuhan Ikan Mas. Jurnal Sains Akuakultur Tropis. 2(1):1-10.

Tacon, A. E. J. 1987. The Nutrition and Feeding Formed Fish and Shrimp. a Training Manual Food and Agriculture of United Nation Brazilling, Brazil. 108 p.

Takeuchi, T. 1988. Laboratory Work Chemical Evaluation of Dietary Nutrient, p. 179 - 232. In: T. Watanabe (ed): Fish Nutrition and Mariculture. Kanagawa Fisheris Training Center, Japan Internasional Cooperation Agency, Tokyo.

Watanabe, T. 1988. Fish Nutrition and Mariculture. JICA Texbook The General Aquaculture Course. Kanagawa International Fisheries Training Centre Japan International Coopertion Agency, 348 p.

Yulianingrum, T., Pamukas, N.A., Putra, I. 2017. Pemberian pakan yang difermentasikan dengan probiotik untuk pemeliharaan ikan lele dumbo (Clarias gariepinus) pada teknologi bioflok. Jurnal fakultas perikanan dan kelautan. 4(1).

Zonneveld, N., E.A. Huisman, dan J.H. Boon. 1991. PrinsipPrinsip Budidaya Ikan. Gramedia Pustaka Utama. Jakarta. 318 hlm. 
THIS PAGE INTENTIONALLY LEFT BLANK 